\title{
Leaching behavior of enrofloxacin in three different soils and the influence of a surfactant on its mobility
}

\author{
Zhiyong $\mathrm{Yu}^{1}$, Ayfer Yediler ${ }^{2, *}$, Min Yang ${ }^{1}$, Sigurd Schulte-Hostede ${ }^{2}$ \\ 1. State Key Laboratory of Environmental Aquatic Chemistry, Research Center for Eco-Environmental Sciences, Chinese Academy of Sciences, \\ Beijing 100085, China. E-mail: yzy@ rcees.ac.cn \\ 2. Helmholtz, Zentrum Muenchen, German Research Center for Environmental Health, Institute of Ecological Chemistry, \\ Ingolstaedter Landstrasse. 1, 85764 Neuherberg, Germany
}

Received 15 December 2010; revised 12 April 2011; accepted 18 April 2011

\begin{abstract}
The leaching behaviors of enrofloxacin (ENR), a fluoroquinolone group antibiotic, in three different standard soils, namely sandy, loamy sand and sandy loam were investigated according to OECD guideline 312. In addition, the effects of tenside, sodium dodecylbenzenesulfonate (DBS) on the mobility of ENR in two different soils were studied. The mobility of ENR in all three standard soils was very similar and was mostly (98\%) concentrated on the top 0-5 cm segment of the soils at pH 5.7. The DBS can enhance the mobility of ENR in soils but the impact was in general negligible under the studied conditions.
\end{abstract}

Key words: enrofloxacin; leaching; soil; sodium dodecylbenzenesulfonate

DOI: $10.1016 / \mathrm{S} 1001-0742(11) 60771-7$

\section{Introduction}

Enrofloxacin (ENR, 1,4-dihydro-1-cyclopropyl-7-(3methy lpiperazin-1-piperazinyl)-6-fluoro-4-oxo-3-quinoline-carboxylic acid, CAS: 93106-60-6), a fluoroquinolone group antibiotic, is widely used in livestock production and aquaculture (Tolls, 2001; Uslu et al., 2008; Zhao et al., 2010). Soil residues result mostly from the use of contaminated manure as fertilizer on agricultural land as ENR is degraded only to a small extent during its passage through the animal (Martens et al., 1996). Due to surface runoff and leaching, soils can also act as a source of antibiotic contaminants for the aqueous environment (Picó and Andreu, 2007; Martínez-Carballo et al., 2007; Uslu et al., 2008). ENR has been detected in arable soils in Austria up to $8.3 \mathrm{mg} / \mathrm{kg}$ (Martínez-Carballo et al., 2007) and $0.013-0.204 \mathrm{mg} / \mathrm{kg}$ in manure amended agricultural soils in Turkey (Uslu et al., 2008). Andreu et al. (2007) compared the environmental concentrations of nine fluoroquinolones in soil samples from agricultural fields differing in type of soil and in sewage sludge application, showing the presence of ENR in soil at concentrations with $0.12 \mathrm{mg} / \mathrm{kg}$. Zhao et al. (2010) investigated the residual levels of selected fluoroquinolones, sulfonamides and tetracyclines in 143 animal dung samples collected in 2007 from large scale livestock and poultry farms in eight provinces of China. As a representative FQ, ENR was often detected in dung samples of cows (1.72-46.70

\footnotetext{
* Corresponding author. E-mail: yediler@helmholtz-muenchen.de
}

$\mathrm{mg} / \mathrm{kg}$ ) and chickens (with the highest concentration of $1420.76 \mathrm{mg} / \mathrm{kg}$ ).

Residues of ENR quite often occur in soils but little is known about its fate, or the effects and risks associated with its release into environment (Picó and Andreu, 2007). The soil column leaching tests in the mixture of soils have been demonstrated as a useful approach to provide a proof for assessing the fate and leaching behaviour of pollutants in the environment. Many researchers studied the fate of oxytetracycline, sulphachloropyridazine, tylosin, sulfamethoxazole, ofloxacin and sulfadiazine by soil column leaching experiments (Kladivko et al., 1991; Karthideyan and Bleam, 2003; Kay et al., 2005; Brown et al., 1995; Drillia et al., 2005; Zhang and Huang, 2007; Unold et al., 2009). Their results showed that the sorption of the investigated drugs and the soil organic matter (SOM) influenced the leaching behaviors of chemicals.

The surfactants which are widely applied and discharged to the environment can affect the mobility of antibiotics. sodium dodecylbenzenesulfonate (DBS) e.g., a representative of the linear alkylbenzene sulfonate (LAS) family widely used for domestic and industrial purposes is considered to be able to change the characteristics of soil and influence the mobility of pollutants by affecting the adsorption isotherm of the substances in soils (Yediler et al., 1991; Ou et al., 1995; Xia et al., 2005).

In this study, the leaching behaviour of ENR in three different standard soils, namely, sandy, loamy sand and sandy loam, was studied by column experiments as given 
by OECD guideline 312 (OECD 312, 2004). To study the effect of the surfactants (DBS) on the mobility of the ENR in soils identical column experiments using two different standard soils were also conducted.

\section{Materials and methods}

\subsection{Chemicals and reagents}

Enrofloxacin (ENR) was obtained from Fluka. The structure of ENR is shown in Fig. 1. The molecular weight of ENR is $359.4 \mathrm{~g} / \mathrm{mol}$. The values of dissociation constants $\mathrm{p} K_{\mathrm{a} 1}$ and $\mathrm{p} K_{\mathrm{a} 2}$ were 6.27 and 8.30 respectively, and the values of $K_{\mathrm{d} \text {,solid }}$ ranged from 496 to 3037 and $\log K_{\text {ow }}$ was 1.1 (Tolls, 2001). Individual ENR stock solution of the concentration of $100 \mathrm{mg} / \mathrm{L}$ and DBS stock solution of the concentration of $500 \mathrm{mg} / \mathrm{L}$ were prepared in ultra pure water and stored at $4^{\circ} \mathrm{C}$ in darkness. Sodium dodecylbenzenesulfonate (DBS) (approx. 80\%) was purchased from Sigma. $\mathrm{H}_{3} \mathrm{PO}_{4}\left(85 \%\right.$, Merck), $\mathrm{KH}_{2} \mathrm{PO}_{4}$ (Merck), $\mathrm{Na}_{2}$ EDTA $2 \mathrm{H}_{2} \mathrm{O}$ (Sigma), $\mathrm{CaCl}_{2} \cdot 2 \mathrm{H}_{2} \mathrm{O}$ (Merck) and 98\%-100\% formic acid (Merck) were analytical grade. Methanol (Merck) and acetonitrile (Sigma) were HPLC grade.

\subsection{Soil samples}

Three different standard soils obtained from LUFA, Speyer, Germany, were used for the column leaching experiments. Their characteristics which might affect the fate of ENR in soils are shown in Table 1.

\subsection{Spiking procedure}

To obtain the recovery rates of the extraction methods, one gram of freeze dried soil sample was spiked with $200 \mu \mathrm{L}$ of standard solution containing $5 \mathrm{mg} / \mathrm{L}$ ENR prepared in ultra pure water, to yield $1.0 \mu \mathrm{g} / \mathrm{g}$. To avoid the modification of the subsequent extraction the spiking solvent water was evaporated overnight under the fume board.

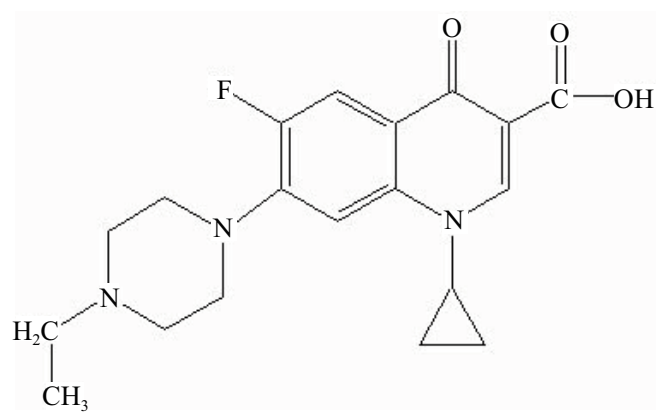

Fig. 1 Structure of enrofloxacin (ENR).

\subsection{Extraction methods}

$\mathrm{Na}_{2}$ EDTA $2 \mathrm{H}_{2} \mathrm{O}$ of $0.2 \mathrm{~g}$ and $5 \mathrm{~mL}$ of $\mathrm{pH} 3$ buffer $(27.2$ $\mathrm{g}$ of $\mathrm{KH}_{2} \mathrm{PO}_{4}$ and $1.35 \mathrm{~mL}$ of $\mathrm{H}_{3} \mathrm{PO}_{4}$ in $1 \mathrm{~L}$ water): acetonitrile $(50: 50, V / V)$ was added to glass centrifuge tubes containing $1 \mathrm{~g}$ of soil samples. Samples were vortex mixed (Vortex Genie 2, Scientific Industries, USA) for $60 \mathrm{sec}$ and placed into an ultrasonic bath for $15 \mathrm{~min}$. They were then centrifuged for $5 \mathrm{~min}$ at $5000 \times g$ and $20^{\circ} \mathrm{C}$. The supernatant was transferred to an other $250 \mathrm{~mL}$ conical flask and the extraction procedure was repeated three times with additions of 4,3 , and $3 \mathrm{~mL}$ of $\mathrm{pH} 3$ buffer. Extracts were combined and made up to $200 \mathrm{~mL}$ with ultra pure water to decrease the acetonitrile content prior to the clean up step by solid phase extraction (Uslu et al., 2008; Blackwell et al., 2004).

\subsection{Solid phase extraction}

Clean up and pre-concentration was performed using a combination of solid phase cartridges namely SAX (strong anion exchange; $1000 \mathrm{mg}$ sorbent and $6 \mathrm{~mL}$ capacity) from Phenomenex, USA and HLB (polymeric, $500 \mathrm{mg}$ sorbent, $6 \mathrm{~mL}$ capacity) from Waters, Milford, USA. They were placed in tandem to simultaneously remove negatively charged humic material (SAX) and retain the veterinary medicine (HLB) (Uslu et al., 2008). The SAX cartridge was placed on the top of the HLB and both columns were conditioned first with $3 \mathrm{~mL}$ of $\mathrm{MeOH}$ and then $3 \mathrm{~mL}$ of $\mathrm{pH}$ buffer. Extracts of $200 \mathrm{~mL}$ were then passed through both SPE-columns and the columns were washed with 10 $\mathrm{mL}$ of ultra pure water and dried for $10 \mathrm{~min}$ under vacuum. Then the SAX cartridge was removed and the elution was carried out with $4 \mathrm{~mL}$ methanol through HLB. Eluates were evaporated to about $150 \mu \mathrm{L}$ under gentle $\mathrm{N}_{2}$ stream and made up to $1 \mathrm{~mL}$ using the mobile phase $(0.02 \mathrm{~mol} / \mathrm{L}$ $\mathrm{H}_{3} \mathrm{PO}_{4}$ acid containing water:acetonitrile $(80: 20, \mathrm{~V} / \mathrm{V})$ ) and transferred to HPLC amber vials.

\subsection{Soil column experiments}

As given by OECD guideline 312, glass columns with an inner diameter of $5 \mathrm{~cm}$ and a height of $30 \mathrm{~cm}$ were used for the column leaching studies. The columns were packed with different amounts of air-dried and sieved $(<2 \mathrm{~mm})$ standard soils up to a height of $25 \mathrm{~cm}$ (700 $\mathrm{g}$ of SP1, $600 \mathrm{~g}$ of SP2 and $650 \mathrm{~g}$ of SP3). After packing, the soil columns were pre-wetted with $200 \mathrm{~mL}$ artificial rain $(0.01$ $\mathrm{mol} / \mathrm{L} \mathrm{CaCl} 2: 1.47 \mathrm{~g} \mathrm{CaCl}_{2} \cdot 2 \mathrm{H}_{2} \mathrm{O}$ dissolved in $1 \mathrm{~L}$ ultra pure water) with a $\mathrm{pH}$ of 5.7 from bottom to top to displace the air in the soil pores by water. Subsequently they were allowed to equilibrate and the excess water was drained off by gravity. The water holding capacities of the soil

Table 1 Physical and chemical characteristics of standard soils

\begin{tabular}{|c|c|c|c|c|c|c|c|c|}
\hline \multirow[t]{2}{*}{ Soil No. } & \multirow[t]{2}{*}{ Soil texture } & \multicolumn{4}{|c|}{ Composition of soil particles (\%) } & \multirow{2}{*}{$\begin{array}{l}C_{\text {org }} \\
(\%)\end{array}$} & \multirow{2}{*}{$\begin{array}{l}\mathrm{CEC}^{\mathrm{a}} \\
(\mathrm{meqv} / 100 \mathrm{~g})\end{array}$} & \multirow[t]{2}{*}{$\mathrm{pH}$} \\
\hline & & Clay $(<2 \mu \mathrm{m})$ & Silt $(2-20 \mu \mathrm{m})$ & Fine sand $(20-200 \mu \mathrm{m})$ & Coarse sand $(>200 \mu \mathrm{m})$ & & & \\
\hline SP1 & Sandy & 3.6 & 4.6 & 31.9 & 59.9 & 1.15 & 6 & 6.0 \\
\hline SP2 & Loamy sand & 7.5 & 7.4 & 42 & 43.1 & 2.36 & 11 & 5.6 \\
\hline SP3 & Sandy loam & 8.9 & 11.3 & 51.3 & 26.3 & 1.02 & 9 & 6.2 \\
\hline
\end{tabular}

${ }^{a}$ Cation exchange capacity. 
columns utilized in the experiments were assumed to be 160, 170 and $160 \mathrm{~mL}$ for SP1, SP2 and SP3, respectively. As a next step the surfaces of the soil columns were covered by a glass fibre filter (Carl Roth Gmbh + Co., Germany, $0.45 \mu \mathrm{m}$ ) then $250 \mathrm{~mL}$ of ENR standard solution of $10 \mathrm{mg} / \mathrm{L}$ adjusted to $\mathrm{pH} 5.7$, with $1 \mathrm{~mol} / \mathrm{L} \mathrm{NaOH}$ was carefully dropped evenly over the surface of the soil columns. At the same time the valve of the glass column was screwed loosely to make the solution drained off drop by drop until the almost dryness of the top soil. Then 250 $\mathrm{mL}$ of the artificial rain was added to the soil columns drop-wise with the help of separatory funnels during 36 hr. The leaching depth was equivalent to the two months' average rainfall of the globe. For the study of the effect of DBS on the mobility of ENR, the artificial rain was replaced by $500 \mathrm{mg} / \mathrm{L}$ DBS solution (DBS dissolved in artificial rain). Then the soil was squeezed out with the help a peristaltic device and sectioned in three segments namely $0-5 ; 5-15$; and $15-25 \mathrm{~cm}$. Every soil segment was mixed intensively, transferred into the rockered flasks and frozen at $-20^{\circ} \mathrm{C}$ overnight before freeze drying for $30 \mathrm{hr}$ (OECD, 2004).

Triplicate leaching columns were packed to study the leaching behaviours of ENR with three different standard soils namely, sandy, loamy sand and sandy loam. In addition one blank leaching column was run as control. To study the effect of surfactants (DBS) only two standard soils (sandy and loamy sand) showing significant difference in their characteristic were selected. For the DBS experiments duplicate leaching columns were packed with each soil and one black column was run as control.

\subsection{HPLC analysis}

The HPLC analyses were performed with a 1100 series LC chromatograph system (Agilent Technologies, Germany) equipped with a fluorescence detector and an automated injection system. ENR standard solutions and sample extracts were analysed on LC column (ZORBAX SB-C18, $5 \mu \mathrm{m}, 4.6 \times 150 \mathrm{~mm})$ at $30^{\circ} \mathrm{C}$ with an injection volume of $10 \mu \mathrm{L}$. Isocratic elution was carried out with 0.02 $\mathrm{mol} / \mathrm{L} \mathrm{H}_{3} \mathrm{PO}_{4}$ acid containing water:acetonitrile (80:20, $V / V)$ at a flow rate of $0.8 \mathrm{~mL} / \mathrm{min}$. The excitation and emission wavelengths for ENR were 280 and $450 \mathrm{~nm}$, respectively. Analyses of sodium dodecylbenzenesulfonate were performed with the same instrument at a column temperature of $26^{\circ} \mathrm{C}$ with an injection volume of $20 \mu \mathrm{L}$. Isocratic elution was carried out with ultra pure water: $\mathrm{MeOH}(15: 85, V / V)$ at a flow rate of $0.8 \mathrm{~mL} / \mathrm{min}$. The detection wavelength for DBS was $225 \mathrm{~nm}$ (Ramos et al., 2003; Golet et al., 2001).

\subsection{Calibration curves, instrument detection limit and recovery}

Good linearity was obtained for ENR with a concentration of $0.1,0.2,0.5,1,2 \mathrm{mg} / \mathrm{L}$ and DBS with a concentration of $0.5,1,2,5,10 \mathrm{mg} / \mathrm{L}$ in mobile phase. Correlation coefficients were higher than 0.999 in all cases. The instrument detection limit of ENR was $0.5 \mu \mathrm{g} / \mathrm{L}(\mathrm{S} / \mathrm{N}$ =10). The analytical method had a good applicability for detecting the ENR in soil.

The results of recovery experiments indicate that the recovery rates of ENR in sandy soil (76.9\%-79.5\%) and loamy sand $(76.5 \%-77.2 \%)$ were slightly higher than that in sandy loam soil $(70.2 \%-71.7 \%)$, which might be related with the contents of organic carbon and the composition of particles like clay and their CEC in different soils (Nowara et al., 1997; Figueroa-Diva et al., 2010).

\section{Results and discussion}

\subsection{Leaching behavior of ENR in standard soils}

The standard soils, sandy (SP1), loamy sand (SP2) and sandy loam (SP3), were used to conduct the first series of the column experiments. The results are presented in Fig. 2. ENR was not detectable in the blank samples.

The highest concentration of ENR in soil was detected in the upper layer of $0-5 \mathrm{~cm}$ after leaching with artificial rain. Despite of the wide range differences in the levels of organic carbon $(1.15 \%-2.36 \%)$, clay $(3.6 \%-8.9 \%)$ and cation exchange capacity (6-11 meqv/100 g), the three standard soils demonstrated similar adsorption behaviours for ENR: ENR was mostly (98\%) concentrated on the top $0-5 \mathrm{~cm}$ segment. All of the three soils showed a high affinity to ENR, assumingly due to the formation of irreversibly bound residues.

The results are in accordance with the previous studies. Tolls et al. (2001) found that the transportation of pharmaceuticals depended largely on the sorption behaviours of soils. Nowara et al. (1997) found that over $90 \%$ of the applied ENR was adsorbed on five soils from different geographic areas of Germany. At clay minerals ENR adsorption was even higher, namely $>98 \%$ as a result of adsorption between the mineral layers of soils. Uslu et al. (2008) studied the sorption of ENR on three types of soils and the highest distribution coefficient was achieved for loamy sand (ENR $K_{\mathrm{d}}=97 \mathrm{~L} / \mathrm{kg}$ and $K_{\mathrm{f}}=0.56$ ) with the highest organic carbon. PH value has a strong effect on the adsorption of ENR in soil and ENR has strong tendency for sorption at $\mathrm{pH}=5.7$. ENR can move rapidly from the water compartment into soil mainly because it is the most lipophilic compounds with $K_{\mathrm{oc}}$ of $15,800 \mathrm{~L} / \mathrm{kg}$ (Picó and Andreu, 2007). However, different values of $K_{\mathrm{oc}}$ and $K_{\mathrm{d}}$ of

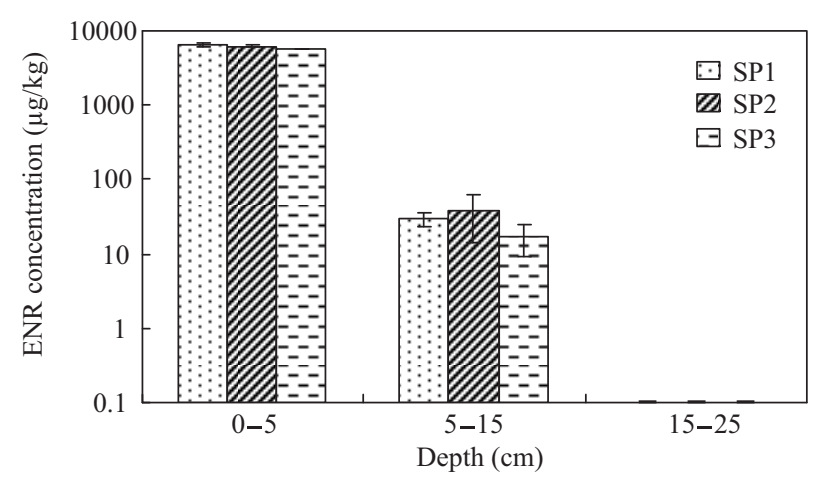

Fig. 2 ENR concentrations at different sections of soils after column leaching experiment. SP1, sandy; SP2, loamy sand; SP3, sandy loam. (250 mL ENR standard solution containing $10 \mathrm{mg} / \mathrm{L}$ ENR was added; $n=3)$. 
ENR were acquired for different soils ( $K_{\mathrm{oc}}: 16506-768740$ L/kg, $K_{\text {d,solid }}: 260-5612$ L/kg) (Nowara et al., 1997). The reason for this will be explored in the future studies.

Martens et al. (1996) suggested that the degradation of ENR in soil is hindered considerably by adsorption to soil constituents, probably soil organic matter. Fluoroquinolones were tightly bound to feces and soils and hardly bio-available, leading to their apparent recalcitrance. On the basis of our results, we conclude that the degradation of ENR in soil will be hampered considerably due to the firm adsorption to soil constituents.

It should be noted that insoluble calcium salt might have formed due to the mixing of ENR and calcium ions containing in artificial rain, which could be a reason responsible for the low leaching behavior of ENR. Therefore, the impact of calcium ions to the leaching behavior of ENR in soils will be investigated by using solutions free from calcium ions in the future.

\subsection{Effect of DBS on the fate of ENR in soil}

The effect of sodium dodecylbenzenesulfonate on the mobility of ENR was investigated. The leaching results of standard soils SP1 and SP2 are presented in Fig. 3. ENR was detected in the $15-25 \mathrm{~cm}$ section after DBS leaching, showing that DBS enhanced the mobility of ENR in two different soils. However, the concentrations of ENR in the 15-25 cm section after DBS leaching were only 10$21 \mu \mathrm{g} / \mathrm{kg}$. The DBS can enhance the mobility of ENR in soils but the impact was in general negligible under the conditions used. However, further studies will be required to elucidate the leaching behavior of ENR under calcium ion-free conditions.

Results obtained by several authors studying the effect of a widely used surfactant (LAS) on the adsorption of phenanthrene (PAH) on soils indicated a significant increase on the mobility or accumulation of phenanthrene in soils and plants (Yediler et al., 1991; Ou et al., 1995; Xia et al., 2005). The different $K_{\mathrm{d}}$ values between PAHs (approximately $250 \mathrm{~L} / \mathrm{kg}$ ) and ENR (3000-6000 L/kg) might be the major reason for the different effects exhibited by the surfactants on the mobility of target organic compounds in soils. For a compound with a high $K_{\mathrm{d}}$ value,

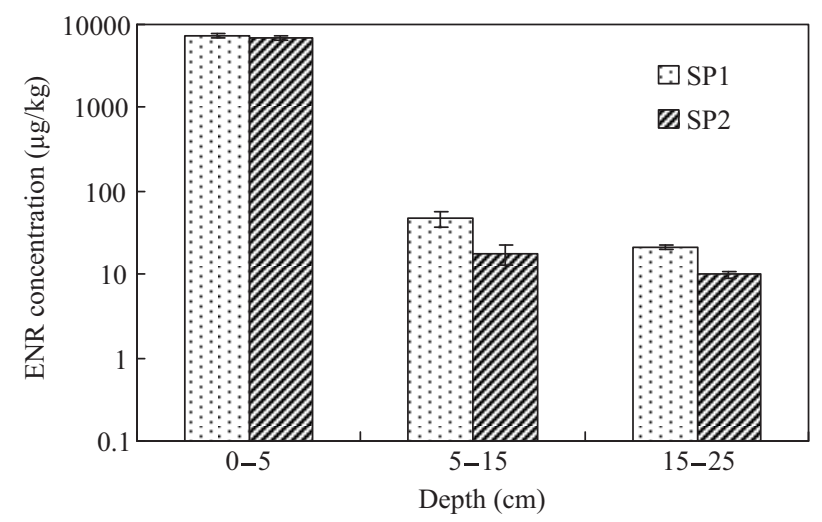

Fig. 3 ENR concentrations at different sections of soils after column leaching experiment for two soils (SP1 and SP2) under the presence of DBS $(250 \mathrm{~mL}$ ENR standard solution containing $10 \mathrm{mg} / \mathrm{L}$ ENR was added; $n=2)$. the effect of the surfactants will be very limited. Therefore, the mobility behavior of ENR was not affected perceptibly by the surfactant.

\section{Conclusions}

A range of laboratory soil column experiments have been carried out to investigate the leaching behavior of enrofloxacin in three standard soils and the effect of sodium dodecylbenzenesulfonate on the mobility of ENR in two standard soils. The sorption of ENR in three different standard soils is very strong and the mobility is weak at $\mathrm{pH}$ 5.7. DBS can enhance the mobility of ENR in soils but the impact was in general negligible under the conditions used. It is important to consider the potential harmful effect of ENR on the soil microbial community when the soil respiration, nitrification of ammonia, etc. are considered as shown in this study.

\subsection{Acknowledgments}

This work has been carried out at the Helmholtz Zentrum Muenchen, Research Center for Environmental Health, Institute of Ecological Chemistry, Germany. It was supported by the German Federal Ministry of Education and Research (BMBF) and by the National Natural Science Foundation of China (No. 50921064, CHN 04/010).

\section{References}

Andreu V, Blasco C, Pico Y, 2007. Analytical strategies to determine quinolone residues in food and the environment. Trends in Analytical Chemistry, 26(6): 534-556.

Blackwell P A, Lützhøft H C H, Ma H P, Halling-Sørensen B, Boxall A B A, Kay P, 2004. Ultrasonic extraction of veterinary antibiotics from soils and pig slurry with SPE clean-up and LC-UV and fluorescence detection Talanta, 64(4): 1058-1064.

Brown C D, Hodgkinson R A, Rose D A, Syers J K, Wilcockson S J, 1995. Movement of pesticides to surface waters from a heavy clay soil. Pesticide Science, 43(2): 131-140.

Drillia P, Dokianakis S N, Fountoulakis M S, Kornaros M, Stamatelatou K, Lyberatos G, 2005. On the occasional biodegradation of pharmaceuticals in the activated sludge process: The example of the antibiotic sulfamethoxazole. Journal of Hazardous Materials, 122(3): 259-265.

Figueroa-Diva R A, Vasudevan D, Mackay A A, 2010. Trends in soil sorption coefficients within common antimicrobial families. Chemosphere, 79(8): 786-793.

Golet E M, Alder A C, Hartmann A, Ternes T A, Walter G, 2001. Trace determination of fluoroquinolone antibacterial agents in urban wastewater by solid-phase extraction and liquid chromatography with fluorescence detection. Analytical Chemistry, 73(15): 3632-3638.

Karthideyan K G, Bleam F W, 2003. Occurrence of antibiotics in wastewater effluents and their mobility in soils: a case study for Wisconsin. DNR project: \#169.

Kay P, Blackwell P A, Boxall A B A, 2005. Column studies to investigate the fate of veterinary antibiotics in clay soils following slurry application to agricultural land. Chemosphere, 60(4): 497-507.

Kladivko E J, Van Scoyoc G E, Monke E J, Oates K M, Pask W, 
1991. Pesticide and nutrient movement into subsurface tile drains on a silt loam soil in Indiana. Journal of Environmental Quality, 20(1): 264-270.

Martens R, Wetzstein H G, Zadrazil F, Capelari M, Hoffmann P, Schmeer N, 1996. Degradation of the fluoroquinolone enrofloxacin by wood-rotting fungi. Applied and Environmenatal Microbiology, 62(11): 4206-4209.

Martínez-Carballo E, González-Barreiro C, Scharf S, Gans O, 2007. Environmental monitoring study of selected veterinary antibiotics in animal manure and soils in Austria. Environmental Pollution, 148(2): 570-579.

Nowara A, Burhenne J, Spiteller M, 1997. Binding of fluoroquinolone carboxylic acid derivatives to clay minerals. Journal of Agricultural and Food Chemistry, 45(4): 14591463.

OECD, 2004. Organisation for Economic Cooperation and Development (OECD) guidelines for the testing of chemicals 312: Leaching in soil columns.

Ou Z Q, Yediler A, He Y W, Kettrup A, Sun T H, 1995. Effects of linear alkylbenzene sulfonate (LAS) on the adsorption behaviour of phenanthrene on soils. Chemosphere, 30(2): 313-325.

Picó Y, Andreu V, 2007. Fluoroquinolones in soil-risks and challenges. Analytical and Bioanalytical Chemistry, 387(4): 1287-1299.

Ramos M, Aranda A, Garcia E, Reuvers T, Hooghuis H, 2003. Simple and sensitive determination of five quinolones in food by liquid chromatography with fluorescence detection.
Journal of Chromatography B, 789(2): 373-381.

Tolls J, 2001. Sorption of veterinary pharmaceuticals in soils: a review. Environmental Science Technology, 35(17): 33973406.

Unold M, Kasteel R, Groeneweg J, Vereecken H, 2009. Transport and transformation of sulfadiazine in soil columns packed with a silty loam and a loamy sand. Journal of Contaminant Hydrology, 103(1-2): 38-47.

Uslu M Ö, Yediler A, Balcıoğu I A, Schulte-Hostede S, 2008. Analysis and sorption behavior of fluoroquinolones in solid matrices. Water Air Soil Pollution, 190(1-4): 55-63.

Xia J, Yediler A, Song Y F, Sun T H, Kettrup A, 2005. Effect of linear alkylbenzene sulphonate (LAS) on the mineralization, metabolism and uptake of 14C-phenanthrene in a model ecosystem (water-lava-plant-air). Chemosphere, 61(5): 741-751.

Yediler A, Kettrup A, Nüßlein F, Korte F, 1991. Mobility of $\mathrm{O}$-cresol in sandy soil in the presence of linear alkylbenzene sulfonate. Toxicological and Environmental Chemistry, 3132: 119-125.

Zhang H C, Huang C H, 2007. Adsorption and oxidation of fluoroquinolone antibacterial agents and structurally related amines with goethite. Chemosphere, 66(8): 1502-1512.

Zhao L, Dong Y H, Wang H, 2010. Residues of veterinary antibiotics in manures from feedlot livestock in eight provinces of China. Science of the Total Environment, 408(5): 10691075. 